\title{
Incretin-based therapies: new treatments for type 2 diabetes in the new millennium
}

This article was published in the following Dove Press journal:

Therapeutics and Clinical Risk Management

19 August 2009

Number of times this article has been viewed

\section{Joan Khoo \\ Christopher K Rayner \\ Karen $L$ Jones \\ Michael Horowitz}

Discipline of Medicine, Royal Adelaide Hospital, Adelaide, South Australia, Australia
Correspondence: Michael Horowitz Discipline of Medicine, Level 6 Eleanor Harrald Building, Royal Adelaide Hospital, The University of Adelaide, SA 5005, Australia

Tel +6I (0) $88222550 \mathrm{I}$

Fax +6I (0) 882233870

Email michael.horowitz@adelaide.edu.au

\begin{abstract}
The advent of 'incretin-based therapies' - GLP-1 agonists and dipeptidyl-peptidase-4 inhibitors - which result in improvements in glycemic control comparable to those with existing oral hypoglycemic agents, and potentially improve cardiovascular and pancreatic $\beta$-cell function, represents a major therapeutic advance in the management of type 2 diabetes. Gastrointestinal adverse effects occur commonly with GLP-1 agonists, and rarely with DPP-4 inhibitors, but are dose-dependent and usually transient. The low risk of hypoglycemia, and beneficial or neutral effects on body weight, render GLP-1 agonists and DPP-4 inhibitors suitable alternatives to insulin secretagogues and insulin in overweight and elderly patients. Incretin-based therapies also improve quality of life in patients with type 2 diabetes, and may be cost-effective in the long term.
\end{abstract}

Keywords: incretin, type 2 diabetes, therapy, GLP-1, DPP-4

\section{Introduction}

Type 2 diabetes mellitus (T2DM) is well-recognized as a major problem worldwide, with substantial impacts on morbidity, mortality, quality of life, and health care costs. Because current treatment regimens for T2DM do not effectively target the fundamental defects in glucose-mediated insulin secretion and beta-cell loss, an increasing proportion of T2DM patients progress to requiring insulin. Accordingly, the recent advent of so-called 'incretin-based therapies', the incretin hormones being glucagon-like peptide-1 (GLP-1) and glucose-dependent insulinotropic peptide (GIP), which have the potential to address these defects, represents a major paradigm shift in management.

The prevalence of T2DM has been rising dramatically, reflecting aging populations and the increasing prevalence of obesity, so that by 2025 an estimated 350 million people worldwide will be affected. ${ }^{1}$ T2DM is characterized by peripheral insulin resistance, impaired regulation of hepatic glucose production, and declining $\beta$-cell function. The last is evident initially as impaired first-phase insulin secretion in response to oral, or intravenous, glucose and progresses at a variable rate to absolute insulin deficiency, reflecting $\beta$-cell failure, which is present in a substantial number of T2DM patients at diagnosis. This defect, rather than insulin resistance, may be a primary abnormality in T2DM, particularly in Asian populations, in which postprandial hyperglycemia is often apparent before elevation of fasting plasma glucose. ${ }^{1}$ The development, and progression, of the macrovascular (cardiovascular, cerebrovascular and peripheral vascular disease) and, particularly, microvascular 
(nephropathy, neuropathy, retinopathy) complications of diabetes can be reduced substantially by optimizing glycemic control. ${ }^{2,3}$ However, many patients fail to achieve the target glycated hemoglobin $\left(\mathrm{HbA}_{1 \mathrm{c}}\right)$ of $\leq 7 \%$ suggested by the American Diabetes Association and European Association for the Study of Diabetes, despite use of maximal doses of oral hypoglycemic agents (OHAs) in combination. ${ }^{4}$ Moreover, concerns have recently been raised over the risk of malignancy, particularly breast cancer, with the use of sulfonylureas and insulin (especially glargine). ${ }^{5}$

\section{Current therapy for type $\mathbf{2}$ diabetes}

The majority of OHAs in common use are insulin sensitizers and/or insulin secretagogues. Older patients, in particular, are vulnerable to impaired awareness of hypoglycemia with consequent neuroglycopenia and adverse cardiovascular effects, dictating the need for particular caution with therapies that increase the risk of hypoglycemia. A history of severe hypoglycemia in older T2DM patients has been associated with a greater risk of dementia, which increases with the number of hypoglycemic episodes. ${ }^{6}$ There has been considerable interest in the outcomes of the recent $\mathrm{ADVANCE}^{7}$ and $\mathrm{ACCORD}^{8}$ trials, which failed to show any cardiovascular benefit of lowering $\mathrm{HbA}_{1 \mathrm{c}}$ to below 7\% in patients recently diagnosed with T2DM. Significantly, in the ACCORD trial, combination therapy using high doses of thiazolidinediones (TZD), sulfonylureas (SU), metformin, and insulin, was associated with an increase in cardiovascular and all-cause mortality, possibly because of hypoglycemia. Metformin and TZDs decrease insulin resistance and hepatic glucose output, but are contraindicated in patients with significant renal and/or cardiac dysfunction, both of which occur frequently in T2DM.

There is now compelling evidence that postprandial hyperglycemia (PPG) is a dominant contributor to overall glycemia, particularly when $\mathrm{HbA}_{1 \mathrm{c}}$ is below $8.5 \%,{ }^{9}$ and that PPG increases cardiovascular risk. ${ }^{10,11}$ However, no current OHA specifically targets PPG, with the possible exception of $\alpha$-glucosidase inhibitors such as acarbose, which decrease the rate of glucose absorption, but whose use is limited by a high prevalence of gastrointestinal adverse effects (GI AEs); and the meglitinides repaglinide and nateglinide, which are insulin secretagogues (though the risk of hypoglycemia is lower than that with sulfonylureas). Furthermore, higher doses, and combinations, of OHA are progressively required in the majority of patients. ${ }^{4}$ The reasons for this are diverse and include difficulty in compliance with lifestyle modifications (diet, exercise) and medications; but perhaps, most importantly, the failure of these OHAs to target several underlying pathophysiologic mechanisms of T2DM, particularly inappropriately high glucagon secretion, impaired first-phase insulin secretion, and progressive $\beta$-cell failure. Hence, the availability of drugs that stimulate insulin secretion in a physiological fashion, ie, at elevated glucose levels but not during euglycemia, are weight-neutral or promote weight loss, and have beneficial effects to preserve $\beta$-cell function, would represent a major asset in the management of T2DM. These properties are evident with recently developed medications that target the incretin system, namely the glucagon-like peptide-1 agonists and the dipeptidyl peptidase-IV inhibitors, which form the major focus of the review.

\section{The incretin effect - implications for pathophysiology and management of T2DM}

Subsequent to the discovery of insulin, La Barre reported in 1932 that a substance produced in the upper intestine had the capacity to cause hypoglycemia without stimulating exocrine pancreatic secretion, which he termed 'incrétine' (incretin), and envisaged its use for the treatment of diabetes. ${ }^{12}$ However, more than three decades would elapse before the incretin effect', ie, greater insulin release in response to an oral glucose load than an isoglycemic intravenous infusion, was demonstrated in 1964 by concurrent reports from both sides of the Atlantic. ${ }^{13,14}$ The known incretin hormones, glucose-dependent insulinotropic polypeptide(GIP), a 42-amino acid hormone produced by K-cells in the proximal small intestine, and glucagon-like peptide-1 (GLP-1), a 30-amino acid peptide synthesized and secreted by L-cells in the ileum and colon, were not isolated until $1970{ }^{15}$ and $1985,{ }^{16}$ respectively.

In healthy people, up to $70 \%$ of post-glucose insulin secretion is mediated by incretins. ${ }^{17}$ However, in T2DM patients, the insulin response to oral glucose is blunted in comparison to non-diabetic control subjects, ${ }^{18}$ suggesting impairment of the incretin effect. The actions of incretins on the defects in glucose metabolism, pancreatic function and energy intake in T2DM patients are shown in Table 1. In T2DM patients during hyperglycemic clamp studies, infusion of GLP-1, but not GIP, stimulates insulin secretion, ${ }^{19}$ establishing that the insulinotropic effect of GLP-1 is relatively well-preserved in T2DM, despite possibly lower levels, when compared to non-diabetic subjects. ${ }^{20}$ On the other hand, GIP levels are essentially normal in T2DM but GIP-stimulated second-phase insulin secretion is 
Table I Actions of incretins on the defects in glucose handling, $\beta$-cell function, and energy intake in type 2 diabetes patients

\begin{tabular}{ll}
\hline Defects in type 2 diabetes & Actions of incretins \\
\hline $\begin{array}{l}\text { Impaired glucose-stimulated insulin secretion and } \\
\text { lack of postprandial biphasic response }\end{array}$ & Restoration of glucose-dependent insulinotropic effect and first-phase response \\
Hyperglucagonemia & Suppression of glucagon secretion \\
Defective hypoglycemia counter-regulation & Glucagon secretion, and loss of insulinotropic effect, when plasma glucose is low \\
Reduced $\beta$-cell mass and insulin content & $\begin{array}{l}\text { Increased synthesis of proinsulin, possible increased } \beta \text {-cell mass or differentiation } \\
\text { of islet precursor cells into } \beta \text {-cells }\end{array}$ \\
Accelerated $\beta$-cell apoptosis & $\begin{array}{l}\text { Possible inhibition of toxin-induced } \beta \text {-cell apoptosis } \\
\text { Normal, retarded or accelerated gastric emptying }\end{array}$ \\
Hypercaloric energy intake, obesity & $\begin{array}{l}\text { Slowing of gastric emptying } \\
\text { Suppression of appetite/increased satiety, weight loss }\end{array}$ \\
\hline
\end{tabular}

markedly diminshed ${ }^{21}$ (although it has recently been reported that reversal of poor glycemic control in T2DM improves the insulin response to both GIP and GLP-1) ${ }^{21}$ Hence, the development of incretin-based therapies for T2DM has hitherto focused on GLP-1, rather than GIP.

In both T2DM and healthy humans, circulating levels of intact GLP-1 decrease rapidly (half-life $\sim 2$ minutes) due to inactivation by the enzyme, dipeptidyl peptide- 4 (DPP-4), such that biologically active GLP-1 represents only $10 \%$ to $20 \%$ of total plasma levels. ${ }^{22}$ Among the truncated forms of GLP-1, GLP-1 (7-36) was found to be more potent compared to other metabolites, such as the $9-36$ form. ${ }^{23}$ The secretion of GLP-1 depends on the rate of delivery of carbohydrate to the small intestine, and is thus influenced by the rate of gastric emptying. ${ }^{24}$ GLP-1 activates specific G-protein-coupled receptors on $\beta$-cells to stimulate insulin secretion at a threshold glucose concentration of $3.7 \mathrm{mmol} / \mathrm{L}$, and also reduces glucose-dependent glucagon secretion, possibly in a paracrine fashion by insulin, or via GLP-1 receptors on $\alpha$-cells, ${ }^{25}$ although the precise mechanism for glucagon suppression is unknown. The role of endogenous GLP-1 in glucoregulation was established by animal and human studies - GLP-1-receptor knockout mice display impaired glucose tolerance and glucose-stimulated insulin secretion. ${ }^{26}$ Administration of the GLP-1 receptor antagonist, exendin (9-39), inhibited postprandial insulin secretion and concomitantly increased plasma glucose in mice, ${ }^{27}$ and accelerated gastric emptying in rats. ${ }^{28}$ Similarly, treatment of non-diabetic human subjects with exendin 9-39 results in defective glucose-stimulated insulin secretion, reduced glucose uptake, increased glucagon levels, and, possibly, accelerated gastric emptying. ${ }^{29-31}$ Slowing of gastric emptying may be as, if not more, important for postprandial glycemic control than stimulating insulin, given that variations in gastric emptying account for about $35 \%$ of the variance in the glycemic response to $75 \mathrm{~g}$ oral glucose loads in healthy subjects, ${ }^{32}$ as well as T2DM patients. ${ }^{33}$ The relationship of glycemia with gastric emptying is also evident for the ingestion of solid carbohydrate-containing food. ${ }^{34,35}$

Exogenous GLP-1 has diverse effects on pancreatic endocrine function and gut motility. Importantly, it has no significant insulinotropic effects below a glucose threshold $\sim \mathrm{mmol} / \mathrm{L},{ }^{36}$ and the counterregulatory release of glucagon in response to hypoglycemia is preserved, even when GLP-1 is administered. Exogenous GLP-1 also stimulates insulin gene transcription and other steps in insulin biosynthesis, ${ }^{37}$ and, in in vitro studies, has a trophic effect on $\beta$-cells by increasing proliferation and neogenesis, and inhibiting apoptosis, ${ }^{38,39}$ which has the potential to retard or reverse $\beta$-cell failure, the fundamental defect in T2DM. In rats, GLP-1 infusion has been reported to increase insulin secretion in response to feeding, and reduce glucagon release and postprandial glycemia. ${ }^{40}$ Exogenous GLP-1 has also been shown to inhibit energy intake and gastric emptying in rats. ${ }^{41}$ In humans with T2DM, overnight GLP-1 infusions lowered blood glucose by restoring first-phase insulin secretion and improving $\beta$-cell function to levels that were comparable to non-diabetic subjects. ${ }^{42}$ Preprandial boluses of GLP-1 were also effective in improving postprandial glucose levels. ${ }^{43}$ Administration of exogenous GLP-1, resulting in supraphysiological levels in peripheral blood, stimulated glucose-mediated insulin secretion while suppressing glucagon and gastric emptying in T2DM patients with poor glycemic control. ${ }^{44}$ In contrast, the insulin response to a carbohydrate-containing meal in healthy subjects was found to be decreased by exogenous GLP-1 in healthy subjects, because of slower gastric emptying causing lower post-load blood glucose levels. ${ }^{45}$ In elderly T2DM patients whose OHA had been discontinued, continuous GLP-1 infusion for 12 weeks enhanced postprandial insulin secretion, and insulin-mediated glucose 
disposal, while maintaining satisfactory glycemic control $\left(\mathrm{HbA}_{1 \mathrm{c}} \sim 7 \%\right) .{ }^{46} \mathrm{In}$ another study, ${ }^{47}$ sustained improvements of insulin secretory capacity and insulin sensitivity were accompanied by reductions in $\mathrm{HbA}_{1 \mathrm{c}}(\sim 1 \%)$ and weight $(\sim 2 \mathrm{~kg})$ with supraphysiological (60 to $70 \mathrm{pmol} / \mathrm{L}$ ) levels of GLP-1 maintained by 6 weeks of subcutaneous infusion. Accordingly, the mechanisms by which exogenous GLP-1 reduces postprandial glycemia in both healthy subjects and T2DM patients include delaying the entry of nutrients into the intestine, as well as increasing the insulin, and suppressing the glucagon, response to carbohydrate.

In addition to glycemic control, GLP-1 may have beneficial cardiovascular effects. Continuous GLP-1 infusion increases myocardial insulin sensitivity and glucose uptake, leading to improved left ventricular (LV) contractility, as evidenced by a significant rise in LV ejection fraction from $\sim 30 \%$ to $40 \%$ in both non-diabetic and diabetic patients after acute myocardial infarction, ${ }^{48}$ and in patients with chronic heart failure. ${ }^{49}$ Perioperative (12 hours before and 48 hours after) GLP-1 infusion in T2DM patients who underwent coronary artery bypass grafting not only improved glycemic control, but also reduced hospital mortality and requirements for inotropic agents. ${ }^{50}$ A shorter, purely postoperative (12 hours after), period of intravenous GLP-1 also improved glycemic control and reduced the need for inotropic support in a group of T2DM patients after bypass surgery. ${ }^{51}$ Endothelial function is improved by GLP-1, which induces vasodilation in coronary artery grafts of patients with ischemic heart disease, ${ }^{52}$ and increases flow-mediated dilatation in brachial arteries of healthy humans. ${ }^{53}$ GLP-1 is thought to act by both GLP-1 receptor-dependent andindependent pathways, via its metabolites GLP-1 (7-36) and GLP-1 (9-36) respectively. ${ }^{54}$

The encouraging outcomes of studies of GLP-1 administration in T2DM have led to the development of drugs that enhance GLP-1 activity: synthetic long-acting agonists (such as exenatide and liraglutide) that are resistant to degradation by DPP-IV and could thus be administered less frequently, and inhibitors of DPP-IV (such as sitagliptin and vildagliptin) that increase endogenous GLP-1 levels. GLP-1 agonists and DPP-IV inhibitors are discussed in the following sections.

\section{GLP-I agonists \\ Exenatide (synthetic exendin-4) and exenatide LAR}

Exenatide (Byetta $^{\circledR}$; Eli Lilly and Co.), an injectable GLP-1 receptor agonist, was approved by the US Food and Drug
Administration (FDA) in 2005 as an adjunct therapy for T2DM patients who fail to achieve satisfactory glycemic control on metformin in combination with SU and/or TZD, and is currently available in the United States, the European Union, Australia and several Asian countries. It was developed from exendin-4, found in the saliva of the gila monster lizard, ${ }^{55}$ has approximately 50\% homology with human GLP-1, but binds more avidly to GLP-1 receptors, and is resistant to degradation by DPP-4, thus prolonging its duration of effect. ${ }^{56}$ Exenatide is administered twice daily in a dose of 5 or $10 \mu \mathrm{g}$ by subcutaneous injection. Reductions in fasting and postprandial glucose are mediated by the combined effects of glucose-dependent insulin secretion, suppression of glucagon release, and, in the case of postprandial glycemia, perhaps predominantly by the slowing of gastric emptying and the resulting delayed entry of nutrients into the small intestine. ${ }^{57}$ Acutely, postprandial glucose levels are decreased by up to $75 \%$ primarily as a result of the substantial, and dose-dependent, slowing of gastric emptying, ${ }^{58}$ associated with a reduction in plasma insulin levels in absolute terms. As a result of delayed gastric emptying (the magnitude of which differs substantially between individuals), oral medication such as contraceptive pills and antibiotics, whose efficacy depends on reaching a threshold concentration, are best taken at least an hour before exenatide. ${ }^{59}$ As exenatide is primarily cleared by the kidneys, its use is contraindicated in patients with end-stage renal disease. ${ }^{59}$

Exenatide has been studied as monotherapy, as well as in combination with OHAs. In drug-naïve T2DM patients, a dose of $5 \mu \mathrm{g}$ twice daily (bid), for 4 weeks, followed by $10 \mu \mathrm{g}$ bid for 26 weeks, reduced mean $\mathrm{HbA}_{1 \mathrm{c}}(\sim 1 \%)$, fasting glucose $(\sim 1 \mathrm{mmol} / \mathrm{L}$, ) and weight $(\sim 3 \mathrm{~kg})$, compared to non-significant reductions with placebo. ${ }^{60}$ Three large, randomized, placebo-controlled, 30-week trials compared the efficacy and tolerability of exenatide 5 or $10 \mu \mathrm{g}$ bid added to metformin, ${ }^{61}$ sulfonylureas (SU), ${ }^{62}$ or both, ${ }^{63}$ in T2DM patients with $\mathrm{HbA}_{1 \mathrm{c}} 7.5 \%$ to $11 \%$ and body mass index (BMI) 27 to $45 \mathrm{~kg} / \mathrm{m}^{2}$, who were inadequately controlled on metformin and/or SU. Exenatide $10 \mu \mathrm{g}$ bid reduced $\mathrm{HbA}_{1 \mathrm{c}}$ by $0.8 \%$ to $1.0 \%, 40 \%$ of patients achieving a $\mathrm{HbA}_{1 \mathrm{c}} \leq 7.0 \%$. The weighted mean decrease in $\mathrm{HbA}_{1 \mathrm{c}}$ in these studies was $1.0 \%$ (CI $0.8 \%$ to $1.2 \%)^{64}$, equating to a 4.2 odds ratio for attaining $\mathrm{HbA}_{1 \mathrm{c}}<7.0 \%$, and reductions of $\sim 1.5 \mathrm{mmol} / \mathrm{L}$ in fasting glucose and $1.4 \mathrm{~kg}$ in body weight. An open-label 52-week extension of these trials in overweight patients indicated that exenatide has a sustained beneficial effect on glycemic control: $\sim 50 \%$ of these patients achieved $\mathrm{HbA}_{1 \mathrm{c}} \leq 7 \%$ and mean weight loss was $4.4 \mathrm{~kg}$ 
after 82 weeks. ${ }^{65}$ Pancreatic $\beta$-cell function (assessed by the homeostasis model of assessment, HOMA) improved by $20 \%$ in T2DM patients on a TZD, with or without metformin, who were treated with exenatide, when compared to patients in whom placebo was added to their existing OHA; $;{ }^{66}$ however, this may reflect the improvement in glycemic control per se, rather than an absolute increase in $\beta$-cell mass or longevity. In these trials, the magnitude of the reduction in $\mathrm{HbA}_{1 \mathrm{c}}$ with exenatide was greater with higher pre-treatment $\mathrm{HbA}_{1 \mathrm{c}}{ }^{64}$ indicating greater benefits of GLP-1 agonist treatment in patients with relatively worse glycemic control. Twice-daily exenatide was also compared with insulin in an open-label trial of patients with long-standing T2DM suboptimally controlled on stable doses of OHA. Patients on exenatide and insulin glargine had comparable decreases in $\mathrm{HbA}_{1 \mathrm{c}}(\sim 1 \%)$, with lower postprandial excursions in the exenatide group, ${ }^{67}$ and greater reduction in fasting and 'premeal' glucose in the insulin-treated group. In addition, body weight decreased $(-2.3 \mathrm{~kg})$ progressively over 26 weeks in patients treated with exenatide, with significant loss $(-1.9 \mathrm{~kg})$ even in those who did not report nausea, and increased $(1.8 \mathrm{~kg})$ in patients on insulin. In a cross-over trial, $\mathrm{HbA}_{1 \mathrm{c}}$ fell by about $1.4 \%$ with both treatments, ${ }^{68}$ while postprandial excursions were less and weight loss occurred with exenatide treatment. Similar trends were seen in another study comparing exenatide with premixed biphasic insulin aspart in overweight T2DM patients who were suboptimally controlled with OHA. ${ }^{69}$ Hence, it appears that exenatide is non-inferior to insulin for glycemic control, and has the advantage of causing weight loss in obese T2DM patients.

Exenatide LAR, a long-acting release form, has been developed for once-weekly subcutaneous injection, but has not yet been marketed. In a 15-week trial of T2DM patients suboptimally controlled by metformin or diet and exercise, exenatide LAR $2 \mathrm{mg} /$ week reduced mean $\mathrm{HbA}_{1 \mathrm{c}}$ by $1.7 \%$, fasting glucose by $\sim 2 \mathrm{mmol} / \mathrm{L}$, and weight by $3.8 \mathrm{~kg} .{ }^{70}$ In T2DM patients with suboptimal control on diet and exercise or $\geq 1$ OHA, this dose of exenatide LAR resulted in comparable reductions in $\mathrm{HbA}_{1 \mathrm{c}}$, fasting glucose and weight after 30 weeks of treatment, with a reduced incidence and severity of nausea and other GI AEs than, exenatide $10 \mu \mathrm{g}$ bid. ${ }^{71}$ Exenatide LAR may produce smaller effects in postprandial glucose excursions, perhaps because inhibition of gastric emptying is less (the latter has hitherto only been assessed using the kinetics of paracetamol absorption), than twice-daily exenatide. This needs to be explored more fully, but may suggest that continuous GLP-1 receptor activation slows gastric emptying less than repeated, acute exposure to
GLP-1 agonists, and may also mitigate the GI AEs. Exenatide LAR may potentially be a useful alternative for patients who are less tolerant of frequent injections, though its place in therapy remains to be determined.

\section{Liraglutide}

Liraglutide has 97\% homology with GLP-1, and is longeracting than exenatide because of an attached free fatty acid derivative that increases non-covalent binding to albumin, and renders it more resistant to DPP-4 degradation, which slows renal clearance and absorption from the subcutaneous injection site. ${ }^{72}$ Its half-life is $\sim 12$ hours, allowing it to be administered once daily $;^{73}$ while its onset of action is slower than exenatide, it is effective and well tolerated in doses of up to $1.9 \mathrm{mg} /$ day. ${ }^{74,75}$ Liraglutide has recently been recommended for marketing authorization (under the trade name Victoza ${ }^{\circledR}$; Novo Nordisk) as combination treatment with metformin and/or SU, or metformin \pm TZD in T2DM patients with suboptimal control, by the Committee for Medicinal Products for Human Use (CHMP) under the European Medicines Agency (EMEA), with final marketing authorization expected from the European Commission by June $2009 .{ }^{76}$ Liraglutide improves glycemic control and increases insulin secretion in response to carbohydrate loads. ${ }^{68-73}$ Effects on gastric emptying or appetite have not been observed thus far, despite its efficacy in reducing body weight. Liraglutide monotherapy for 14 weeks reduced $\mathrm{HbA}_{1 \mathrm{c}}$, fasting glucose, and weight, and increased the proportion of subjects achieving $\mathrm{HbA}_{1 \mathrm{c}}<7 \%$ compared to placebo, in a phase 2 randomized double-blind trial of patients with suboptimal control on diet or $1 \mathrm{OHA},{ }^{74}$ the greatest effects being seen with a daily dose of $1.9 \mathrm{mg}$. Phase 3 trials in the Liraglutide Effect and Action in Diabetes (LEAD) program investigated the effects of liraglutide as monotherapy, or in combination with various OHAs. A 52-week monotherapy trial (LEAD-3) demonstrated that liraglutide $1.2 \mathrm{mg}$ and $1.8 \mathrm{mg}$ daily led to greater reductions in $\mathrm{HbA}_{1 \mathrm{c}}$ and fasting glucose than glimepiride $8 \mathrm{mg}$ daily. ${ }^{77} \mathrm{In}$ addition, body weight decreased significantly by $\sim 2 \mathrm{~kg}$ in patients on liraglutide compared to a mean gain of $1 \mathrm{~kg}$ on glimepiride, and the incidence of minor hypoglycemia in the liraglutide group was $\sim 10 \%$, compared to $24 \%$ of patients on glimepiride. A 26-week comparison of the efficacy and safety of liraglutide, glimepiride, and placebo, in combination with metformin, found that liraglutide resulted in a comparative improvement in glycemic control, with weight loss and a lower incidence of hypoglycemia. ${ }^{78} \mathrm{~A}$ 26-week, double-blind, placebo-controlled study (LEAD-4 Met + TZD) 
demonstrated that liraglutide when combined with metformin and rosiglitazone was effective for glycemic control. ${ }^{79}$ Another 26-week study found that when either liraglutide, placebo, or rosiglitazone was added to glimepiride, liraglutide produced the greatest reductions in $\mathrm{HbA}_{1 \mathrm{c}}$ and fasting glucose ${ }^{80}$ and adding liraglutide to glimepiride stabilized body weight. The beneficial effect of liraglutide on body weight was also seen in a trial of patients on metformin and glimepiride, which compared the addition of liraglutide (mean weight loss of $1.8 \mathrm{~kg}$ ) with that of insulin glargine (weight gain of $1.6 \mathrm{~kg}$ ), ${ }^{81}$ Liraglutide-induced weight loss reflected a reduction in visceral and subcutaneous fat mass, and lean mass increased slightly. ${ }^{82}$ Markers of $\beta$-cell function, such as the proinsulin:insulin ratio $,{ }^{74} \mathrm{HOMA},{ }^{80}$ and first- and second-phase insulin responses during arginine-stimulated hyperglycemia, ${ }^{83}$ were also improved by liraglutide. Hence, like exenatide, liraglutide is effective in improving and maintaining glycemic control as monotherapy or in combination with OHA, and in reducing body weight, with the advantage over twice-daily exenatide of requiring less frequent injections.

\section{Safety and tolerability of GLP-I agonists}

Hypoglycemia is clearly less common with the use of GLP-1 agonists than with SU or insulin, presumably reflecting the glucose-dependent effects of the former on endogenous insulin secretion. The frequency of minor hypoglycemic episodes (about 5\%) was comparable to placebo in studies of exenatide with metformin as the background therapy, though the incidence of hypoglycemia increased when exenatide improved glycemic control in conjunction with SU, and decreased in tandem with reduction in SU dose. ${ }^{64}$ Severe hypoglycemia was rare when exenatide was combined with either metformin or TZDs. ${ }^{61,63,66}$ The incidence of severe hypoglycemia was about $1.5 \%$ in the exenatide/glargine parallel-group comparative study, ${ }^{67}$ but none of the episodes was severe, required medical attention or necessitated withdrawal of treatment. Minor hypoglycemia has been reported in $\sim 10 \%$ of patients taking liraglutide as monotherapy ${ }^{74}$ or in combination with metformin and/or TZD, ${ }^{79}$ though the incidence is increased to $\sim 25 \%$ when liraglutide is added to $\mathrm{SU} .^{78,80}$

The adverse effects of GLP-1 agonists are chiefly gastrointestinal. ${ }^{58-86}$ Nausea is the most common with both the short-acting and LAR formulations of exenatide, ${ }^{58-68}$ with mild to moderate self-reported nausea in $\sim 35 \%$ of patients on exenatide $5 \mu \mathrm{g}$ bid and up to half of the patients receiving $10 \mu \mathrm{g}$ bid. ${ }^{84}$ In most patients the frequency, and severity, peaks in the first 8 weeks of treatment and decreases thereafter, ${ }^{64,66}$ and is likely to be a central GLP-1 effect, unrelated to the slowing of gastric emptying. ${ }^{84}$ Other GI AEs, such as diarrhea and constipation, are less common, and are also usually transient and mild. In clinical trials, treatment discontinuation because of GI AEs (nausea, vomiting, diarrhea, anorexia, abdominal pain) occurred in about $5 \%$ of patients. The risk of exenatide-induced nausea can apparently be minimized by progressive escalation in dosage. ${ }^{85}$ The frequency of nausea may be less in patients on exenatide LAR. ${ }^{70,71}$ Liraglutide is also associated with GI AEs, which are dose-dependent, the most common being transient mild-to-moderate nausea, which occurs in 5\% to $15 \%$ of patients. ${ }^{73-77}$ A patient-reported evaluation of GI AEs using the Gastrointestinal System Rating Scale (GSRS), ${ }^{84}$ as part of a 14-week phase 2 trial, ${ }^{74}$ indicated that GI symptoms are not usually severe (maximum 2 on a 7 -point scale), and occur mainly in the first 2 weeks of treatment, returning to baseline thereafter. In a 26-week study of T2DM patients with suboptimal glycemic control on OHA, once-daily liraglutide was associated with less persistent nausea than twice-daily exenatide, which may be attributable to smaller fluctuations in concentration of the GLP-1 receptor agonist. ${ }^{86}$

Anti-exenatide antibodies are evident in about half to two-thirds of patients on exenatide, ${ }^{64}$ or exenatide LAR, ${ }^{70}$ but do not appear to affect either glycemic control or adverse events. A higher prevalence of injection-site discomfort and anti-exenatide antibodies were seen in patients on the LAR form. Anti-liraglutide antibodies have been detected in $\sim 10 \%$ of patients, but, again, do not appear to have adverse effects, or influence glycemic control. ${ }^{81}$

\section{GLP-I agonists in development}

New GLP-1 agonists have demonstrated improvement in fasting and postprandial glucose control in phase III trials, with apparently fewer GI AEs than currently marketed compounds. Albiglutide, a DPP-4-resistant GLP-1 analog which is administered weekly, reduced fasting and postprandial glucose levels without causing hypoglycemia in healthy subjects $^{87}$ and T2DM patients. ${ }^{88}$ A dose of $32 \mathrm{mg}$ reduced 24-hour mean weighted glucose by $35 \mathrm{mg} / \mathrm{dL}(\sim 2 \mathrm{mmol} / \mathrm{L})$ at day 2 and $56 \mathrm{mg} / \mathrm{dL}(\sim 3 \mathrm{mmol} / \mathrm{L})$ at day 9 after treatment in T2DM subjects. Of note, the frequency and severity of GI AEs of albiglutide were comparable to placebo. Taspoglutide, another once-weekly GLP-1 agonist, reduced $\mathrm{HbA}_{1 \mathrm{c}}(\sim 0.9 \%$ to $1.2 \%$ ), as well as fasting and postprandial glucose levels at doses of 10 or $20 \mathrm{mg}$ in T2DM, in combination with metformin for 8 weeks, with a low incidence of hypoglycemia. ${ }^{89}$ 
Weight loss was also significant, especially in the group receiving $20 \mathrm{mg} /$ week $(-2.8 \mathrm{~kg})$.

\section{DPP-4 inhibitors}

Prevention of GLP-1 degradation by pharmacological DPP-4 inhibition in pigs, ${ }^{90}$ and genetic inactivation in DPP-4 knockout mice, ${ }^{91}$ increase endogenous total GLP-1 levels, leading to increased insulin secretion and reduced fasting and postprandial glucose concentrations. These findings have led to the development of once-daily, orally-active DPP-4 inhibitors to increase the incretin effect. DPP-4 activity is reduced by almost $100 \%$ within 15 to 30 minutes of oral administration of the DPP-4 inhibitors sitagliptin or vildagliptin, producing a 2-fold increase in mean active GLP-1 levels (to 15 to $25 \mathrm{pmol} / \mathrm{L}$ ), with a duration of inhibition in excess of 16 hours because of initial rapid binding to DPP-4, followed by a slow phase of tight binding, ${ }^{92}$ so that effects persist for 24 hours after administration of a single dose of sitagliptin ${ }^{93}$ and vildagliptin..$^{94}$ DPP-4 inhibition increases GLP-1 and GIP levels by 2 - to 3 -fold, while reducing glucagon, ${ }^{92}$ although the magnitude of the rise in GLP-1 is dependent on the type of nutrient ingested. The pharmacokinetics of sitagliptin and vildagliptin are not affected by age, gender, ethnicity or body mass index, and no significant drug interactions have hitherto been noted..$^{95}$

\section{Sitagliptin}

Sitagliptin (Januvia ${ }^{\circledR}$; Merck and Co, Inc.) was approved for use in a dose of $100 \mathrm{mg}$ once daily, by the FDA in 2006 and subsequently in the EU, Australia and Asia, for the improvement of glycemic control in combination with metformin and/or a sulfonylurea when diet and exercise plus OHA do not result in adequate glycemic control. ${ }^{96}$ In drug-naïve T2DM patients, sitagliptin monotherapy is more effective than placebo in reducing $\mathrm{HbA}_{1 \mathrm{c}}$ (by up to $1 \%$ ) and fasting glucose (by up to $18 \mathrm{mg} / \mathrm{dL}$ ). ${ }^{97}$ Greater benefits in glycemic control were seen with sitagliptin $100 \mathrm{mg}$ daily, compared to placebo, over a period of 24 weeks in T2DM patients already on metformin ${ }^{98,99}$ and pioglitazone, ${ }^{100}$ and when added to sulfonylureas (with or without metformin). ${ }^{101}$ It was non-inferior to glipizide when added to ongoing metformin therapy. ${ }^{102}$ Metformin stimulates GLP-1 release, increasing both active and total GLP-1 levels by 2-fold, but does not act as a DPP-4 inhibitor, and, accordingly, has a synergistic effect with sitagliptin, to increase both active GLP-1 ( 4-fold). ${ }^{103}$ A fixed-dose combination of sitagliptin and metformin (Janumet ${ }^{\circledR}$; Merck and Co, Inc.) has recently been developed. An improvement in $\beta$-cell function has been suggested by a reduction in the proinsulin ratio and increase in insulin levels with sitagliptin, compared to placebo..$^{97,98,100}$ The effect of sitagliptin on gastric emptying has not been reported. Unlike GLP-1 agonists, sitagliptin is not associated with changes in body weight. ${ }^{97-102}$ Sitagliptin is thus a useful add-on therapy to OHA in T2DM patients who are not overweight, especially those with suboptimal control on maximum doses of metformin. Dose adjustment of sitagliptin is recommended in patients with renal insufficiency. ${ }^{104}$

\section{Vildagliptin}

Vildagliptin (Galvus ${ }^{\circledR}$; Novartis) was approved in the EU in 2008 , for use in combination with metformin and/or TZD (50 mg twice daily), or with an SU (50 mg once daily), and is pending approval by the FDA. ${ }^{105}$ Vildagliptin monotherapy was shown to be superior to placebo in reducing $\mathrm{HbA}_{1 \mathrm{c}}$ (by $0.4 \%$ to $0.8 \%$ ), fasting (by $\sim 10$ to $20 \mathrm{mg} / \mathrm{dL}$ ) and postprandial glucose, ${ }^{106}$ and non-inferior compared to rosiglitazone ${ }^{107}$ in randomized, double-blinded 24-week trials. The addition of vildagliptin to metformin further improved glycemic control $\left(\mathrm{HbA}_{1 \mathrm{c}}\right.$ reduction $0.5 \%$ to $\left.1.2 \%\right) .{ }^{108,109}$ The combination of vildagliptin with pioglitazone reduced fasting glucose to a greater extent than did vildagliptin or pioglitazone alone, ${ }^{110}$ and vildagliptin is not inferior to pioglitazone when added to metformin. ${ }^{111}$ Vildagliptin has been shown to increase insulin and C-peptide responses to glucose by up to $100 \%,{ }^{108,112}$ suggesting improvements in $\beta$-cell function. ${ }^{113}$ DPP-4 inhibition by vildagliptin does not apparently slow gastric emptying, possibly due to the relatively modest elevation in plasma GLP-1 levels, compared to administration of exogenous GLP-1 agonists. ${ }^{114}$

\section{Safety and tolerability of DPP-4 inhibitors}

Neither sitagliptin ${ }^{97-102}$ nor vildagliptin ${ }^{106-114}$ appear to increase the risk of hypoglycemia when used as monotherapy, or in combination with metformin or TZD, though the incidence of mild-moderate hypoglycemia was increased by approximately 2 -fold to $\sim 4 \%$ to $5 \%$ when sitagliptin was added to SU. ${ }^{101,102}$ DPP-4 inhibitors have not been associated with significant GI AEs, and appear to be safe and well-tolerated in patients with moderate to severe renal insufficiency (including those with end-stage disease on hemodialysis) if doses are adjusted according to creatinine clearance. ${ }^{115}$ An increased risk (odds ratio $1.34,95 \%$ CI 1.10 to 1.64 ) of nasopharyngitis and all-cause infections (sinusitis, viral upper respiratory tract infections, urinary tract infections) has been observed with the use of sitagliptin, ${ }^{95}$ and hypersensitivity reactions (anaphylaxis, angioedema and exfoliative dermatitis) have 
been reported within the first 3 months of sitagliptin therapy, ${ }^{96}$ while cases of vildagliptin-associated severe dermatological allergic reactions and elevated liver transaminases, have led to a delay in FDA approval. ${ }^{105}$

\section{DPP-4 inhibitors in development}

Alogliptin and saxagliptin are DPP-4 inhibitors that may be available in the near future: alogliptin is currently under FDA review, while saxagliptin is under review by the EMEA for potential marketing in late 2009. Alogliptin monotherapy is reportedly effective in reducing $\mathrm{HbA}_{1 \mathrm{c}}$, as well as fasting and postprandial glucose levels in T2DM patients in doses of 25 to $400 \mathrm{mg}$ daily. ${ }^{116,117}$ In randomized, placebo-controlled, double-blinded 26-week trials, the addition of alogliptin to metformin ${ }^{118}$ or glyburide ${ }^{119}$ improved $\mathrm{HbA}_{1 \mathrm{c}}$ and fasting glucose without an increased incidence of GI AEs or hypoglycemia. Alogliptin also improved glycemic control and $\beta$-cell function in combination with pioglitazone ${ }^{120}$ or insulin ${ }^{121}$ in animal models. Saxagliptin reduced $\mathrm{HbA}_{1 \mathrm{c}}$ and both fasting and postprandial glucose levels in drug-naïve T2DM patients in a placebo-controlled, randomized, double-blind study, ${ }^{122}$ and evidence from ongoing trials suggests that it may be effective in combination with metformin, ${ }^{123}$ glyburide ${ }^{124}$ or TZD. ${ }^{125}$ Daily doses of alogliptin 12.5 to $25 \mathrm{mg}$ and saxagliptin 2.5 to $10 \mathrm{mg}$ lower $\mathrm{HbA}_{1 \mathrm{c}}$ by $\sim 1 \%$, which is comparable to sitagliptin and vildagliptin in doses of 50 to $100 \mathrm{mg}$ daily, implying greater potency. In addition, no adverse effects attributable to disordered immune function have been reported to date for alogliptin or saxagliptin, ${ }^{126}$ although it should be recognized that most of the clinical data available on the newer DPP-4 inhibitors have been published only in abstract form, and there is less information available about their safety profiles, in comparison with sitagliptin and vildagliptin.

\section{Extraglycemic effects of incretin-based therapies}

In addition to improving glycemic control, GLP-1 agonists may have additional beneficial effects on blood pressure (BP) and plasma lipids, in part, by effects that are apparently independent of weight loss. Exenatide $5 \mu \mathrm{g}$ bid reduced BP by $\sim 9 \mathrm{mmHg}$ from baseline when added to existing antihypertensive therapy and OHA in obese T2DM patients during 26 weeks of treatment, ${ }^{127}$ while mean diastolic and systolic BP (in another trial of obese T2DM patients on 5 to $10 \mu \mathrm{g}$ bid for 82 weeks $^{128}$ ) was reduced by $\sim 4 \mathrm{mmHg}$ and $\sim 6 \mathrm{mmHg}$ respectively, with the greatest reduction seen in patients who lost the most weight. Patients treated with exenatide 5 to $10 \mu \mathrm{g}$ bid for an average of 3.5 years demonstrated significant reductions in triglycerides $(12 \%)$, total cholesterol (5\%), low-density lipoprotein (LDL) cholesterol (6\%), and increases in high-density lipoprotein (HDL) cholesterol (24\%); ${ }^{129}$ again, these beneficial effects were related to the magnitude of weight loss. However, a recent study using exenatide $\mathrm{LAR}^{71}$ found that the mean reductions in systolic $\mathrm{BP}$ over 30 weeks $(-4.7 \mathrm{mmHg})$ and diastolic BP ( $-1.7 \mathrm{mmHg})$ were independent of body weight. In the LEAD studies ${ }^{77-80}$ liraglutide $1.8 \mathrm{mg}$ daily for 2 weeks reduced mean systolic BP by $\sim 2$ to $4.5 \mathrm{mmHg}$, which was also apparently independent of weight loss. Liraglutide was found to lower triglyceride (TG) levels in association with reductions in weight and $\mathrm{HbA}_{1 \mathrm{c}} \cdot{ }^{74}$ Other than weight reduction, the mechanisms by which GLP-1 agonists improve BP and lipids remain unclear. As discussed previously, GLP-1 analogues also have direct beneficial effects on the heart, as shown by animal studies. Both exenatide and GLP-1 (9-36) improve left ventricular performance and decreased infarct size in rat hearts during reperfusion after ischemia. ${ }^{130}$ Liraglutide also induces significant infarct shrinkage in an ischemia-reperfusion injury murine heart preparations. ${ }^{131}$ In T2DM patients, liraglutide reduces levels of the inflammatory markers plasminogen activator inhibitor 1, B-type natriuretic peptide and high-sensitivity C-reactive protein, which are associated with increased cardiovascular risk. ${ }^{132}$

There is also evidence that DPP-4 inhibitors also have beneficial effects on BP and lipids. In non-diabetic patients with moderate hypertension, sitagliptin reduced systolic and diastolic BP by $\sim 2 \mathrm{mmHg}$, compared to placebo, within 5 days at doses of 50 to $100 \mathrm{mg}$ daily. ${ }^{133}$ Sitagliptin also reduced plasma TG by $10 \%$ to $15 \%$ and increased HDL by $\sim 5 \%$ in doses of 25 to $100 \mathrm{mg}$ daily as monotherapy over 12 weeks in T2DM patients. ${ }^{134}$ Vildagliptin lowered total and LDL cholesterol by $\sim 10 \%{ }^{135}$ and TG by up to $15 \%{ }^{122}$ when added to TZD in metformin-resistant patients. Possible mechanisms for the lipid-lowering effects of DPP-4 inhibitors include reduced production of intestinal TG-rich particles after fat-rich meals ${ }^{136}$ and augmentation of lipid mobilization and oxidation, ${ }^{137}$ although the exact mechanisms remain unclear.

Table 2 compares GLP-agonists and DPP-inhibitors.

\section{Unresolved issues and long-term safety of incretin-based therapies}

The slowing of gastric emptying induced by exogenous GLP-1 and GLP-1 agonists may cause concerns over use in T2DM patients with gastroparesis. It is now well recognized 
Table 2 Comparison of GLP-I agonists and DPP-4 inhibitors

\begin{tabular}{|c|c|c|}
\hline & GLP-I agonists & DPP-4 inhibitors \\
\hline Currently marketed & Exenatide (short-acting and long-acting release), liraglutide & Sitagliptin, vildagliptin \\
\hline Mode of action & GLP-I receptor agonist, resistant to degradation by DPP-4 & $\begin{array}{l}\text { Inhibits degradation of GLP-I } \rightarrow \text { increases endogenous } \\
\text { GLP-I level }\end{array}$ \\
\hline Usage & + metformin $\pm S U \pm T Z D$ & + metformin and/or TZD and/or SU \\
\hline Administration & Subcutaneous injection (pen) & Oral (tablet) \\
\hline Reduction in $\mathrm{HbA}_{\mathrm{lc}}$ & $\sim 1 \%$ to $1.5 \%$ & $\sim 0.5 \%$ to $1 \%$ \\
\hline B-cell function & Possibly improved & Possibly improved \\
\hline Extraglycemic benefits & $\begin{array}{l}\downarrow \text { BP } \\
\downarrow \text { Cholesterol, LDL,TG, } \uparrow \text { HDL } \\
\uparrow \text { Left ventricular function, arterial vasodilation } \\
\text { (GLP-I infusion) }\end{array}$ & $\begin{array}{l}\downarrow \text { BP (sitagliptin) } \\
\downarrow \text { Cholesterol, LDL,TG, } \uparrow \mathrm{HDL}\end{array}$ \\
\hline Hypoglycemia & Very low risk & Very low risk \\
\hline Weight & Reduction & Neutral \\
\hline $\mathrm{Gl}$ adverse effects & $\begin{array}{l}\text { Frequent ( } \sim 35 \% \text { to } 50 \% \text {, dose-dependent and usually } \\
\text { self-limited) }\end{array}$ & Uncommon \\
\hline Gastric emptying & Slowed (greatest effect with exenatide) & No effect \\
\hline Other adverse effects & Pancreatitis & $\begin{array}{l}\text { Nasopharyngitis, upper respiratory tract infection, } \\
\text { headache; elevated liver enzymes (vildagliptin) }\end{array}$ \\
\hline
\end{tabular}

Abbreviations: BP, blood pressure; HDL, high-density lipoprotein; LDL, low-density lipoprotein; SU, sulfonylureas; TG, triglycerides; TZD, thiazolidinediones.

that gastric emptying (GE) is delayed in perhaps $30 \%$ of patients with long-standing T2DM, ${ }^{32}$ and correlates poorly with the presence and severity of upper GI symptoms. ${ }^{138}$ In healthy subjects the magnitude of the slowing of GE by exogenous GLP-1 is sufficient to cause 'gastroparesis' in $~ 50 \%,{ }^{45}$ and in T2DM patients the slowing of GE by exenatide is greater when GE is relatively faster. ${ }^{58}$ It is also known that in diabetics with vagal neuropathy, unlike healthy subjects, exogenous GLP-1 fails to relax the proximal stomach. ${ }^{139}$ The implications are that the magnitude of the reduction in postprandial glycemia induced by GLP-1 is likely to depend on GE, and that in patients with autonomic neuropathy-associated gastroparesis (whether symptomatic or not), any further slowing of gastric emptying is likely to be minimal. Both of these hypotheses warrant formal evaluation. Patients with symptomatic gastroparesis have been excluded from the majority of trials of GLP-1 agonists - hence, the issue of whether these drugs exacerbate, or have no effect on symptoms, also remains unresolved.

Post-marketing cases of acute pancreatitis have rarely been reported with exenatide; ${ }^{140}$ however, T2DM patients have a $\sim 3$-fold increased risk of pancreatitis,,${ }^{141}$ as well as other risk factors for pancreatitis including gallstones, obesity, ethanol abuse and severe hypertriglyceridemia. Eight out of the nine reported cases of pancreatitis in the LEAD program occurred in patients on liraglutide. ${ }^{142}$ Studies in animals to evaluate this issue have hitherto failed to clarify whether there is a causal association between pancreatitis and the use of incretin-based therapies. Administration of metformin, sitagliptin, or liraglutide did not increase transcription of genes associated with pancreatitis in mice, and GLP-1 receptor knockout mice did not differ from normal mice in the severity of experimentally induced pancreatitis when treated with exenatide. ${ }^{143}$ However, treatment with sitagliptin and metformin was associated with increased pancreatic ductal turnover, ductal metaplasia, and one case of pancreatitis in rats. ${ }^{144}$

The non-GI AEs associated with sitagliptin and vildagliptin may be related to the immunological properties of DPP-4, which is expressed in many tissues, and has numerous substrates, including GI hormones, neuropeptides, and cytokines. ${ }^{145}$ As DPP-4 is known to be involved in immunoregulation as a T-cell costimulator, and in breakdown of cytokines such as bradykinin and interleukin- 2 and $-1 \beta,{ }^{146}$ inhibition of DPP-4 may have adverse effects on immune function. Indeed, the severity of rheumatoid arthritis has been reported to be inversely related to DPP-4 activity, ${ }^{147}$ and DPP-4 levels are reduced in nasal tissue of patients with chronic rhinosinusitis. ${ }^{146}$ Although DPP-4 inhibition is known to reduce the levels of the cardioprotective GLP-1 metabolite GLP-1 (9-36) which is cleaved from native intact GLP-1, there is hitherto no evidence of adverse cardiovascular effects. ${ }^{101-118}$ As clinical trials involving sitagliptin and vildagliptin evaluated use for a maximum of only 52 weeks, more long-term safety data are required, particularly in view 
of the need for chronic treatment in T2DM, and the presence of DPP-4 in multiple organ systems.

\section{Cost-effectiveness and patient- centered outcomes of incretin- based therapies}

The cost-effectiveness of exenatide, compared to OHA or insulin, has been evaluated in several studies. As add-on therapy to metformin, it is cost-effective compared to pioglitazone and glibenclamide, ${ }^{59}$ and also as monotherapy in drug-naïve patients compared to metformin alone. An analysis, based on data from 314 overweight T2DM patients who completed an 82-week trial of exenatide, ${ }^{65}$ projected that 30 years of treatment with exenatide added to OHA would be cost-effective in comparison to a hypothetical placebo arm, ${ }^{148}$ in terms of improvements in clinical outcomes (glycemic control, weight, BP, and lipids) with concomitant reductions in the risk of micro- and macrovascular complications, increased life expectancy, and improved quality of life. These were associated with incremental cost-effectiveness ratios (ICER) of US\$35,571/life-years gained, and US\$36,133/quality-adjusted life-year, below the threshold ICER of US\$50,000. Using data from the same cohort, a study projected models of long-term complications, life expectancy, quality-adjusted life expectancy, and direct medical costs of patients on exenatide versus those on insulin glargine in the United Kingdom (UK), ${ }^{149}$ and concluded that exenatide was associated with a lower cumulative incidence of most cardiovascular (CVD) complications, including CVD-related death, and was more cost-effective than glargine. However, this study based its analyses on estimated costs of exenatide which ranged from $20 \%$ to $100 \%$ of the US price (US\$161/28 days). Another UK study, which used the actual UK National Health System price of exenatide ( $£ 68 / 28$ days), rather than an estimated cost, found that exenatide was less cost-effective than glargine in a 40 -year projection. ${ }^{150}$ It is evident that the cost-effectiveness of exenatide in relation to insulin glargine is highly dependent on the relative prices of these medications, which vary substantially between countries.

Patient-reported measures, such as quality of life and treatment satisfaction, have also been analyzed, using data from a 26-week randomized, open-label study comparing exenatide to insulin glargine in T2DM patients with suboptimal glycemic control on metformin and sulfonylurea. ${ }^{67}$ This analysis included 228 patients on exenatide and 227 on insulin, with outcomes measured by 5 scales: 1) Diabetes Symptom
Checklist (frequency and perceived discomfort of physical and psychological symptoms associated with diabetes); 2) Diabetes Treatment Flexibility Scale (focusing on patient choices in meals and daily activities); 3) Diabetes Treatment Satisfaction Questionnaire (satisfaction with current treatment regimen); 4) EuroQol-EQ5D (overall health status); and 5) vitality scale of the SF-36 (energy level and fatigue). Both exenatide and insulin groups showed significant improvement from baseline in symptoms, satisfaction with treatment, overall health status, and energy levels. ${ }^{151}$ The authors noted that although exenatide was associated with GI AEs and increased frequency of injections, these did not result in less patient satisfaction, which they attributed to the benefits of weight loss in this treatment group. Hence, the benefits of exenatide therefore appear to outweigh adverse effects, weight loss in particular conferring an advantage over insulin. At present, there are no cost-benefit analyses available for liraglutide.

In relation to the DPP-4 inhibitors, a cost-effectiveness analysis compared the addition of sitagliptin, rosiglitazone or SU to metformin in patients with $\mathrm{HbA}_{1 \mathrm{c}}>6.5 \% .{ }^{152}$ Local health surveys in Austria, Finland, Portugal, Scotland, Spain, and Sweden were used to generate average patient profiles for the analysis, using data on clinical and adverse effects from two recent trials of sitagliptin. ${ }^{102,153}$ Adding sitagliptin was found to be a more cost-effective alternative to the addition of rosiglitazone or an SU, incremental cost-effectiveness ratio values ranging from $€ 5949 / \mathrm{Q} A L Y$ to $€ 20350 / \mathrm{QALY}$, depending on the individual country. However, these studies may not be generalizable to countries outside the EU, because of differences in health care costs and prices of medication. Analysis of the cost-effectiveness of vildagliptin is not currently available.

Given the comparable outcomes of the use of GLP-1 agonists and DPP-4 inhibitors in T2DM for many parameters, their cost-effectiveness is an important issue. An analysis compared estimated six-month total, and diabetes-related, medical costs among 2482 patients on sitagliptin, with 1885 patients on exenatide, in the US. ${ }^{154}$ Exenatide was associated with lower total 6-month direct medical costs (US\$9340 vs US\$9995), despite some component costs being higher with exenatide, ie, those associated with diabetes-related drugs, and diabetes-related medical care including emergency room attendance. Sitagliptin was associated with higher outpatient costs. This study concluded that use of the GLP-1 agonist was associated with higher diabetes-related costs, but lower total medical costs than the DPP-4 inhibitor; however, as with comparisons of incretin therapies with conventional injectable 
and oral medications, the results of this cost-benefit analysis cannot be extrapolated to outside the US.

\section{The place of incretin-based therapies in the treatment of T2DM and impaired glucose tolerance}

The American Association of Clinical Endocrinologists (AACE) currently advocates DPP-4 inhibitor monotherapy for $\mathrm{T} 2 \mathrm{DM}$ patients with $\mathrm{HbA}_{1 \mathrm{c}} 6 \%$ to $7 \%$, or in combination with metformin or TZD if target $\mathrm{HbA}_{1 \mathrm{c}}(\leq 6.5 \%)$ is not achieved, and adding a GLP-1 agonist to SU, metformin, and/or TZD in patients who do not achieve target $\mathrm{HbA}_{1 \mathrm{c}}{ }^{155}$ In contrast, the American Diabetes Association (ADA) and the European Association for the Study of Diabetes (EASD) did not recommend, in their combined consensus statements on standards of medical care in diabetes ${ }^{156}$ and initiation and adjustment of treatment in T2DM, ${ }^{4}$ either GLP-1 agonists or DPP-4 inhibitors as first- or second-tier treatments, despite acknowledging the weight-lowering effect of exenatide, and the utility of exenatide and sitagliptin for improved postprandial glycemic control with an associated low risk of hypoglycemia. It should be recognized that selected groups of patients may benefit from early, or even first-line, use of incretin-based therapies. The weight-lowering effect of GLP-1 agonists is beneficial in the overweight and obese, especially since many add-on therapies (sulfonylurea, TZD and insulin) promote weight gain. As discussed, trials using exenatide reported a dose-dependent reduction in body weight by up to $4.5 \mathrm{~kg}$ in at least 30 weeks. ${ }^{55-65}$

GLP-1 agonists may also have a role in the management of critically ill patients with T2DM, in whom both hyperglycemia and hypoglycemia are risk factors for a poor outcome. GLP-1 infusion appears to reduce plasma glucose significantly in association with increased insulin and suppressed glucagon concentrations, without the risk of hypoglycemia in severely ill patients who were hyperglycemic while receiving total parenteral nutrition, ${ }^{157}$ as well as in fasted diabetic patients who had undergone major surgery. ${ }^{158}$ More recently, GLP-1 infusion has been shown to markedly attenuate the glycemic response to enteral nutrition (arguably the preferred route of nutritional support) in non-diabetic critically ill patients, reflecting its insulinotropic and glucagonostatic properties. ${ }^{159}$ These observations suggest that GLP-1 and/or its agonists have a potential role in the management of hyperglycemia in the critically ill, without the attendant risks of insulin-induced hypoglycemia. The latter were emphasized by the results of the NICE-SUGAR study, in which the use of insulin infusions to achieve target blood glucose 4.5 to $6.0 \mathrm{mmol} / \mathrm{L}$ was shown to increase both hypoglycemia and mortality in critically ill patients. ${ }^{160}$

Although DPP-4 inhibitors are weight-neutral and do not significantly reduce appetite, their lack of GI side effects compared to GLP-1 agonists and metformin, and low risk of hypoglycemia, render them especially suitable for the management of T2DM in older patients, in whom the polypharmacy often required for glycemic control is accompanied by increased risks of hypoglycemia and other adverse effects due to age-related changes in drug metabolism, reduced energy intake, and comorbidities such as cardiovascular and renal impairment. In particular, sulfonylureas are associated with a high risk of hypoglycemia accounting for substantial morbidity and health-care costs in this group. ${ }^{161}$ Studies of sitagliptin ${ }^{97,98,162}$ and vildagliptin ${ }^{106,107,111,163}$ including subjects $\geq 65$ years of age, and patients with moderately severe hepatic ${ }^{164}$ and renal ${ }^{165}$ impairment, suggest that the DPP-4 inhibitors are as effective $\left(\mathrm{HbA}_{1 \mathrm{c}}\right.$ reduction $\left.\sim 1 \%\right)$ and well-tolerated as in younger patients. The DPP-4 inhibitors were also associated with a low incidence $(-1 \%)$ of severe hypoglycemia, and GI and other adverse events such as peripheral edema ( $2 \%$ to $10 \%)$.

\section{Conclusions}

Despite the relatively recent advent of GLP-1 agonists and DPP-4 inhibitors, evidence has rapidly accumulated to support their efficacy and safety in the management of T2DM, as well as their potential for improving cardiovascular and $\beta$-cell function. The low risk of inducing hypoglycemia, and beneficial or neutral effects on body weight, render them attractive alternatives to insulin secretagogues and insulin as add-on therapy to metformin, or even as first-line therapy in selected groups of patients, especially in the overweight and the elderly. Incretin-based medications are likely to be increasingly at the forefront of therapy of T2DM in the new millennium.

\section{Disclosures}

The authors declare no conflicts of interest.

\section{References}

1. IDF Clinical Guidelines Task Force. Global guideline for type 2 diabetes: recommendations for standard, comprehensive and minimal care. Diabet Med. 2006;23:579-593.

2. UKPDS Group. Intensive blood-glucose control with sulphonylureas or inslin compared with conventional treatment and risk of complications in patients with type 2 diabetes (UKPDS 33). Lancet. 1998;352:837-853. 
3. Shichiri M, Kishikawa H, Ohkubo Y, et al. Long-term results of the Kumamoto Study on Optimal Diabetes Control in type 2 diabetic patients. Diabetes Care. 2000;23:B21-B29.

4. Nathan DM, Buse JB, Davidson MB, et al. Medical Management of Hyperglycemia in Type 2 Diabetes: A Consensus Algorithm for the Initiation and Adjustment of Therapy: A consensus statement of the American Diabetes Association and the European Association for the Study of Diabetes. Diabetes Care. 2009;32:193-203.

5. Currie CJ, Poole CD, Gale EA. The influence of glucose-lowering therapies on cancer risk in type 2 diabetes. Diabetologia. 2009 July 2. (Epub ahead of print).

6. Whitmer RA, Karter AJ, Yaffe K, Quesenberry CP Jr, Selby JV. Hypoglycemic episodes and risk of dementia in older patients with type 2 diabetes mellitus. JAMA. 2009;301:1565-1572.

7. The ADVANCE Collaborative Group. Intensive blood glucose control and vascular outcomes in patients with type 2 diabetes. $N$ Engl J Med. 2008;358:2560-2572.

8. The Action to Control Cardiovascular Risk in Diabetes Study Group. Effects of intensive glucose lowering in type 2 diabetes. N Engl J Med. 2008;358:2545-2559

9. Monnier L, Lapinski H, Colette C, et al. Contributions of fasting and postprandial plasma glucose increments to the overall diurnal hyperglycemia of type 2 diabetic patients: variations with increasing levels of $\mathrm{HbA}_{1 \mathrm{c}}$. Diabetes Care. 2003;26:881-885.

10. Ceriello A, Hanefeld M, Leiter L, et al. Postprandial glucose regulation and diabetic complications. Arch Intern Med. 2004;164: 2090-2095.

11. Raz I, Wilson PWF, Strojek K, et al. Effects of prandial versus fasting glycemia on cardiovascular outcomes in type 2 diabetes: the HEART2D trial. Diabetes Care. 2009;32:381-386.

12. La Barre J. Sur les possibilities d'un traitement du diabète par l'incrétine. Bull Acad R Med Belg. 1932;12:620-634.

13. Elrick H, Stimmler L, Hlad CJ, Arai Y. Plasma insulin response to oral and intravenous glucose administration. J Clin Endocrinol Metab. 1964;24:1076-1082.

14. McIntyre N, Holdsworth CD, Turner DA. New interpretation of oral glucose tolerance. Lancet. 1964;II:20-21.

15. Brown JC, Mutt V, Pederson RA. Further purification of polypeptide demonstrating enterogastrone activity. J Physiol. 1970;209: 57-64.

16. Schmidt WE, Siegel EF, Creutzfeldt W. Glucagon-like peptide-1 but not glucagon-like peptide-2 stimulates insulin release from isolated rat pancreatic islets. Diabetologia. 1985;28:704-707.

17. Nauck MA, Homberger E, Siegel EG, et al. Incretin effects of increasing glucose loads in man calculated from venous insulin and C-peptide responses. J Clin Endocrinol Metab. 1986;63:492-498.

18. Nauck MA, Stockmann F, Ebert R, Creutzfeldt W. Reduced incretin effect in type 2 (non-insulin-dependent) diabetes. Diabetologia. 1986;29:46-52.

19. Vilsboll T, Krarup T, Madsbad S, Holst JJ. Defective amplification of the late phase insulin response to glucose by GIP in obese type II diabetic patients. Diabetologia. 2002;45:1111-1119.

20. Kjems LL, Holst JJ, Volund A, Madsbad S. The influence of GLP-1 on glucose-stimulated insulin secretion effects on beta-cell sensitivity in type 2 and non-diabetic subjects. Diabetes. 2003;52:380-386.

21. Højberg PV, Vilsbøll T, Rabøl R, et al. Four weeks of nearnormalisation of blood glucose improves the insulin response to glucagon-like peptide-1 and glucose-dependent insulinotropic polypeptide in patients with type 2 diabetes. Diabetologia. 2009;52:199-207.

22. Deacon CF, Nauck MA, Toft-Nielsen M, Pridal L, Willms B, Holst JJ. Both subcutaneous and intravenously administered glucagon-like peptide-1 are rapidly degraded from the NH2-terminus in type 2-diabetic patients and in healthy subjects. Diabetes. 1995; 44:1126-1131.

23. Kreymann B, Williams G, Ghatei MA, Bloom SR. Glucagon-like peptide 1 7-36: a physiological incretin in man. Lancet. 1987;2: $1300-1304$.
24. O'Donovan DG, Doran S, Feinle-Bisset C, et al. Effect of variations in small intestinal glucose delivery on plasma glucose, insulin, and incretin hormones in healthy subjects and type 2 diabetes. J Clin Endocrinol Metab. 2004;89:3431-3415.

25. Nauck MA, Heimesaat MM, Behle K, et al. Effects of glucagon-like peptide 1 on counterregulatory hormone responses, cognitive function, and insulin secretion during hyperinsulinemic, stepped hypoglycemic clamp experiments in healthy volunteers. J Clin Endocrinol Metab. 2002;87:1239-1246.

26. Scrocchi LA, Brown TJ, MaClusky N, et al. Glucose intolerance but normal satiety in mice with a null mutation in the glucagon-like peptide 1 receptor gene. Nat Med. 1996;2:1254-1258.

27. Tseng CC, Zhang XY, Wolfe MM. Effect of GIP and GLP-1 antagonists on insulin release in the rat. Am J Physiol Endocrinol Metab. 1999;276: E1049-E1054.

28. Imeryuz N, Yegan BC, Bozkurt A, Coskun T, Villanueva-Penacarrilo ML, Uluson NB. Glucagon-like peptide-1 inhibits gastric emptying via vagal afferent-mediated central mechanisms. Am J Physiol Gastrointest Liver Physiol. 1997;273:G920-G927.

29. Schirra J, Sturm K, Leicht P, Arnold R, Goke B, Katschinski M. Exendin (9-39) amide is an antagonist of glucagon-like peptide-1 (7-36) amide in humans. J Clin Invest. 1998;101:1421-1430.

30. Edwards CM, Todd JF, Mahmoudi M, et al. Glucagon-like peptide 1 has a physiological role in the control of postprandial glucose in humans: studies with the antagonist exendin 9-39. Diabetes. 1999;4:86-93.

31. Schirra J, Nicolaus M, Roggel P, et al. Endogenous glucagon-like peptide 1 controls endocrine pancreatic secretin and antro-pyloroduodenal motility in humans. Gut. 2006;55:243-251.

32. Horowitz M, Edelbroek MA, Wishart JM. Relationship between oral glucose tolerance and gastric emptying in normal healthy subjects. Diabetologia. 1993;36:857-862.

33. Jones KL, Horowitz M, Carney BJ. Gastric emptying in early noninsulin diabetes mellitus. J Nucl Med. 1996;37:1643-1648.

34. Mourot J, Thouvenot P, Couet C, Antoine JM, Krobicka A, Debry G. Relationship between the rate of gastric emptying and glucose and insulin responses to starchy foods in young healthy adults. Am J Clin Nutr. 1988;48:1035-1040.

35. O'Donovan D, Horowitz M, Russo A, et al. Effects of lipase inhibition on gastric emptying of, and on the glycaemic, insulin and cardiovascular responses to, a high-fat/carbohydrate meal in type 2 diabetes. Diabetologia. 2004;47:2208-2214.

36. Perfetti R, Merkel P. Glucagon-like peptide-1: a major regulator of pancreatic beta-cell function. Eur J Endocrinol. 2000;143:717-775.

37. Drucker DJ, Phillippe J, Mojsov S, Chick WL, Haener JF. Glucagon-like peptide 1 stimulates gene expression and increases cyclic AMP level in a rat islet cell line. Proc Natl Acad Sci U S A. 1987;84:3434-3438.

38. Farilla L, Bulotta A, Hirshberg B, et al. Glucagon-like peptide-1 inhibits cell apoptosis and improves glucose responsiveness of freshly isolated human islets. Endocrinology. 2003;144:5149-5188.

39. Li L, El-Kholy W, Rhodes CJ, Brubaker PL. Glucagon-like peptide-1 protects beta cells from cytokine-induced apoptosis and necrosis: role of protein kinase B. Diabetologia. 2005;48:1339-1349.

40. Van Dijk G, Lindskog S, Holst JJ, Steffens AB, Ahren B. Effects of glucagon-like peptide-I on glucose turnover in rats. Am J Physiol Endocrinol Metab. 1996;270:E1015-E1021.

41. Chelikani PK, Haver AC, Reidelberger RD. Intravenous infusion of glucagon-like peptide-1 potently inhibits food intake, sham feeding, and gastric emptying in rats. Am J Physiol Regul Integr Comp Physiol. 1997;288:R1695-R1706.

42. Rachman J, Gribble FM, Barrow BA, Levy JC, Buchanan KD, Turner RC. Normalization of insulin responses to glucose by overnight infusion of glucagon-like peptide 1 (7-36) amide in patients with NIDDM. Diabetes. 1996;45:1524-1530.

43. Juntti-Berggren L, Pigon J, Karpe F, et al. The antidiabetogenic effect of GLP-1 is maintained during a 7-day period and improves diabetic dyslipoproteinemia in NIDDM patients. Diabetes Care. 1996;19: 1200-1206. 
44. Willms B, Werner J, Holst JJ, Orskov C, Creutzfeldt W, Nauck MA. Gastric emptying, glucose responses, and insulin secretion after a liquid test meal: effects of exogenous glucagon-like peptide-1 (GLP-1)-(7-36) amide in type 2 (noninsulin-dependent) diabetic patients. $J$ Clin Endocrinol Metab. 1996;81:327-332.

45. Little TJ, Pilichiewicz AN, Russo A, et al. Effects of intravenous GLP-1 on gastric emptying and intragastric distribution in healthy subjects - relationships with postprandial glycemic and insulinemic responses. J Clin Endocrinol Metab. 2006;91:1916-1923.

46. Meneilly GS, Greig N, Tildesley H, Habener JF, Egan JM, Elahi D. Effects of 3 months of continuous subcutaneous administration of glucagon-like peptide- 1 in elderly patients with type 2 diabetes. Diabetes Care. 2003;26:2835-2841.

47. Zander M, Madsbad S, Madsen JL, Holst JJ. Effect of 6-week course of glucagon-like peptide 1 on glycemic control, insulin sensitivity, and beta-cell function in type 2 diabetes: a parallel-group study. Lancet. 2002;359:824-830.

48. Nikolaidis LA, Mankad S, Sokos GG, et al. Effects of glucagonlike peptide-1 in patients with acute myocardial infarction and left ventricular dysfunction after successful reperfusion. Circulation. 2004;109:962-965.

49. Sokos GG, Nikolaidis LA, Mankad S, Elahi D, Shannon RP. Glucagonlike peptide-1 infusion improves left ventricular ejection fraction and functional status in patients with chronic heart failure. J Card Fail. 2006;12:694-699.

50. Sokos GG, Bolokoglu H, German J, et al. Effect of glucagon-like peptide-1 (GLP-1) on glycemic control and left ventricular function in patients undergoing coronary artery bypass grafting. Am J Cardiol. 2007;100:824-829.

51. Müssig K, Oncu A, Lindauer P, et al. Effects of intravenous glucagonlike peptide 1 on glucose control and hemodynamics after coronary artery bypass surgery in patients with type 2 diabetes. Am J Cardiol. 2008;102:646-647.

52. Nystrom T, Gutniak MK, Zhang Q, et al. Effects of glucagon-likep peptide 1 on endothelial function in type 2 diabetes patients with stable coronary artery disease. Am J Physiol Endocrinol Metab. 2004;287: E1209-E1215.

53. Basu A, Charkoudian N, Schrage W, Rizza RA, Basu R, Joyner MJ. Beneficial effects of GLP-1 on endothelial function in humans: dampening by glyburide but not by glimepiride. Am J Physiol Endocrinol Metab. 2007;293:E1289-E1295.

54. Ban K, Noyan-Ashraf MH, Hoefer J, et al. Cardioprotective and vasodilatory actions of glucagon-like peptide 1 receptor are mediated through both glucagon-like peptide-1 receptor-dependent and -independent pathways. Circulation. 2008;117:2340-2350.

55. Eng J, Kleinman WA, Singh L, Singh G, Raufman JP. Isolation and characterization of exendin-4, an exendin-3 analogue, from Heloderma suspectum venom. Further evidence for an exendin receptor on dispersed acini from guinea pig pancreas. J Biol Chem. 1992;267 4108-4115.

56. Thorens B, Porret A, Buhler L, Deng SP, Morel P, Widmann C. Cloning and functional expression of the human islet GLP-1 receptor. Demonstration that exendin-4 is an agonist and exendin (9-39) an antagonist of the receptor. Diabetes. 1993;42:1678-682.

57. Kolterman OG, Buse JB, Fineman MS, Gaines E, Heintz S. Synthetic exendin-4 (exenatide) significantly reduces postprandial and fasting plasma glucose in subjects with type 2 diabetes. $J$ Clin Endocrinol Metab. 2003;88:3082-3089.

58. Linnebjerg H, Park S, Kothare PA, et al. Effect of exenatide on gastric emptying and relationship to postprandial glycemia in type 2 diabetes. Regul Pept. 2008;151:123-129.

59. Cvetkovic RS, Plosker GL. Exenatide: a review of its use in patients with type 2 diabetes mellitus (as an adjunct to metformin and/or a sulfonylurea). Drugs. 2007;67:935-954.

60. Nelson P, Poon T, Guan X, Schnabel C, Wintle M, Fineman M. The incretin mimetic exenatide as a monotherapy in patients with type 2 diabetes. Diabetes Technol Ther. 2007;9:317-326.
61. DeFronzo RA, Ratner RE, Han J, Kim DD, Fineman MS, Baron AD. Effects of exenatide (exendin-4) on glycemic control and weight over 30 weeks in metformin-treated patients with type 2 diabetes. Diabetes Care. 2005;28:1092-1100.

62. Buse JB, Henry RR, Han J, Kim DD, Fineman MS, Baron AD. Effects of exenatide (exendin-4) on glycemic control over 30 weeks in sulfonylureatreated patients with type 2 diabetes. Diabetes Care. 2004;27:2628-2635.

63. Kendall DM, Riddle MC, Rosenstock J, et al. Effects of exenatide (exendin-4) on glycemic control over 30 weeks in patients with type 2 diabetes treated with metformin and a sulfonylurea. Diabetes Care. 2005;28:1083-1091.

64. Amori RE, Lau J, Pittas AG. Efficacy and safety of incretin therapy in type 2 diabetes: systematic review and meta-analysis. JAMA. 2007; $2585-2589$.

65. Blonde L, Klein EJ, Han J, et al. Interim analysis of the effects of exenatide treatment on $\mathrm{A}_{1 \mathrm{c}}$, weight and cardiovascular risk factors over 82 weeks in 314 overweight patients with type 2 diabetes. Diabetes Obes Metab. 2006;8:436-447.

66. Zinman B, Hoogwerf BJ, Duran GS, et al. The effect of adding exenatide to a thiazolidinedione in suboptimally controlled type 2 diabetes. Ann Intern Med. 2007;146:477-485.

67. Heine RJ, Van Gaal LF, Johns D, Mihm MJ, Widel MH, Brodows RG. Exenatide versus insulin glargine in patients with suboptimally controlled type 2 diabetes: a randomized trial. Ann Int Med. 2005;143:559-569.

68. Barnett AH, Burger J, Johns D, et al. Tolerability and efficacy of exenatide and titrated insulin glargine in adult patients with type 2 diabetes previously uncontrolled with metformin or a sulfonylurea: a multinational, randomized, open-label, two-period crossover noninferiority trial. Clin Ther. 2007;29:2333-2348.

69. Nauck MA, Duran S, Kim D, et al. A comparison of twice-daily exenatide and biphasic insulin aspart in patients with type 2 diabetes who were suboptimally controlled with sulfonylurea and metformin: a non-inferiority study. Diabetologia. 2007;50:259-267.

70. Kim D, MacConnell L, Zhuang D, et al. Effects of once-weekly dosing of a long-acting release formulation of exenatide on glucose control and body weight in subjects with type 2 diabetes. Diabetes Care. 2007;30:1487-1493

71. Drucker DJ, Buse JB, Taylor K, et al; DURATION-1 Study Group. Exenatide once weekly versus twice daily for the treatment of type 2 diabetes: a randomised, open-label, non-inferiority study. Lancet. 2008;372:1240-1250.

72. Knudsen LB, Knudsen SM, Wilkem M, et al. Plasma protein binding of NN2211, a long-acting derivative of GLP-1, is important for its efficacy. Diabetes. 2003; A321-A322.

73. Knudsen LB, Nielsen PF, Huusfeldt PO, et al. The pharmacokinetics, pharmacodynamics, safety and tolerability of NN2211, a new longacting GLP-1 derivative, in healthy men. Diabetologia. 2002;45:195-202.

74. Vilsboll T, Zdravokovic M, Le-Thi T, et al. Liraglutide, a longacting human glucagon-like peptide 1 analog, given as monotherapy significantly improves glycemic control and lowers body weight without risk of hypoglycemia in patients with type 2 diabetes. Diabetes Care. 2007;30:1608-1610.

75. Irie S, Matsumura $Y, Z$ dravkovic M, Jacobsen LV, Kageyama S. Tolerability, pharmacokinetics and pharmacodynamics of the oncedaily human GLP-1 analog liraglutide in Japanese healthy subjects: a randomised, double-blind, placebo-controlled dose-escalation study. Int J Clin Pharmacol Ther. 2008;46:273-279.

76. Liraglutide given positive opinion by EMEA. http://www.novonordisk. com/. Accessed May 7, 2009.

77. Garber A, Henry R, Ratner R, et al. Liraglutide versus glimepiride monotherapy for type 2 diabetes (LEAD-3 Mono): a randomized, 52-week, phase III, double-blind, parallel-treatment trial. Lancet. 2009;373:473-481.

78. Nauck M, Frid A, Hermansen K, et al; for the Lead-2 Study Group. Efficacy and safety comparison of liraglutide, glimepiride, and placebo, all in combination with metformin, in type 2 diabetes. Diabetes Care. 2009;32:84-90. 
79. Zinman B, Gerich K, Buse JB, et al. Efficacy and safety of the human GLP-1 analog liraglutide in combination with metformin and TZD in patients with type 2 diabetes mellitus (LEAD-4 Met+TZD). Diabetes Care. 2009;32:1224-1230.

80. Marre M, Shaw K, Brandle M, et al; on behalf of the LEAD-1 SU study group. Liraglutide, a once-daily human GLP-1 analogue, added to a sulphonylurea over 26 weeks produces greater improvements in glycemic and weight control compared with adding rosiglitazone or placebo in subjects with type 2 diabetes (LEAD-1 SU). Diabet Med. 2009;26:268-278.

81. Russell-Jones D. Molecular, pharmacological and clinical aspects of liraglutide, a once-daily human GLP-1 analogue. Mol Cell Endocrinol. 2009;297:137-140.

82. Harder H, Nielsen L, Tu DT, Astrup A. The effect of liraglutide, a long-acting glucagon-like peptide 1 derivative, on glycemic control, body composition, and 24-h energy expenditure in patients with type 2 diabetes. Diabetes Care. 2004;27:1915-1921.

83. Vilsboll T, Brock B, Perrild H, et al. Liraglutide, a once-daily human GLP-1 analogue, improves pancreatic $\beta$-cell function and argininestmulated insulin secretion during hyperglycaemia in patients with type 2 diabetes. Diabet Med. 2008;25:152-156.

84. Horowitz M, Vilsbøll T, Zdravkovic M, Hammer M, Madsbad S. Patient-reported rating of gastrointestinal adverse effects during treatment of type 2 diabetes with the once-daily human GLP-1 analogue, liraglutide. Diab Obes Metab. 2008;10:593-602.

85. Fineman MS, Shen LZ, Taylor K, Kim DD, Baron AD. Effectiveness of progressive dose-escalation of exenatide (exendin-4) in reducing dose-limiting side effects in subjects with type 2 diabetes. Diabetes Metab Res Rev. 2004;20:411-417.

86. Buse JB, Rosenstock J, Sesti G, et al. (The LEAD-6 Study Group). Liraglutide once a day versus exenatide twice a day for type 2 diabetes: a 26-week randomised, parallel-group, multinational, open-label trial (LEAD-6). Lancet. 2009;374:39-47.

87. Bush MA, Matthews JE, De Boever EH. Safety, tolerability, pharmacodynamics and pharmacokinetics of albiglutide, a long-acting glucagon-like peptide-1 mimetic, in healthy subjects. Diab Obes Metab. 2009; 11:498-505.

88. Matthews JE, Stewart MW, De Boever EH. Pharmacodynamics, pharmacokinetics, safety and tolerability of albiglutide, a long-activ glucagon-like peptide-1 mimetic, in patients with type 2 diabetes. J Clin Endocrinol Metab. 2008;93:4810-4817.

89. Nauck MA, Ratner RE, Kapitza C, Berria R, Boldrin M, Balena R. Treatment with the human once-weekly GLP-1 analogue taspoglutide in combination with metformin improves glycemic control and lowers body weight in patients with type 2 diabetes mellitus inadequately controlled with metformin alone: a double-blind placebo-controlled study. Diabetes Care. 2009;32:1237-1243.

90. Deacon CF, Hughes TE, Holst JJ. Dipeptidyl peptidase IV inhibition potentiates the insulinotropic effect of glucagon-like peptide 1 in the anesthetized pig. Diabetes. 1998;47:764-769.

91. Marguet D, Baggio L, Kobayashi T, et al. Enhanced insulin secretion and improved glucose tolerance in mice lacking CD26. Proc Natl Acad Sci U S A. 2000;97:6874-6879.

92. Åhren B, Landin-Olsson M, Jansen PA, et al. Inhibition of dipeptidyl peptidase-4 reduces glycemia, sustains insulin levels and reduces glucagon levels in type 2 diabetes. J Clin Endocrinol Metab. 2004;89:2078-2084.

93. Herman GA, Stevens C, Van Dyck K, et al. Pharmacokinetics and pharmacodynamics of sitagliptin, an inhibitor of dipeptidyl peptidase IV, in healthy subjects: results from two randomized, double-blind, placebocontrolled studies with single oral doses. Clin Pharmacol Ther. 2005; 78:675-688.

94. Mari A, Sallas WM, He YL, et al. Vildagliptin, a dipeptidyl peptidase-IV inhibitor, improves model-assessed beta-cell function in patients with type 2 diabetes. J Clin Endocrinol Metab. 2005;90:4888-4894.

95. Richter B, Bandeira-Echtler E, Bergerhoff K, Lerch C. Emerging role of dipeptidyl peptidase- 4 inhibitors in the management of type 2 diabetes. Vasc Health Risk Man. 2008;4:753-768.
96. Januvia Summary of Product Characteristics. Merck Sharp and Dohme Ltd. www.medicines.org.uk. Accessed January 31, 2009.

97. Raz I, Hanefeld M, Xu L, et al. Efficacy and tolerability of the dipeptidyl peptidase-4 inhibitor sitagliptin as monotherapy in patients with type 2 diabetes. Diabetologia. 2006;49:2564-2571.

98. Charbonnel B, Karasik A, Liu J, Wu M, Meinitnger G. Efficacy and safety of the dipeptidyl peptidase-4 inhibitor sitagliptin added to ongoing metformin therapy in patients with type 2 diabetes inadequately controlled with metformin alone. Diabetes Care. 2006;29:2638-2643.

99. Goldstein B, Feinglos MN, Lunceford JK, Johnson K, WilliamsHerman DE. Effect of initial combination therapy with sitagliptin, a dipeptidyl peptidase- 4 inhibitor, and metformin on glycemic control in patients with type 2 diabetes. Diabetes Care. 2007;30:1979-1987.

100. Rosenstock J, Brazag R, Andryuk PJ, Lu K, Stein P. Efficacy and safety of the dipeptidyl peptidase-4 inhibitor sitagliptin added to ongoing pioglitazone therapy in patients with type 2 diabetes: a 24 -week, multicenter, randomized, double-blind, placebo-controlled, parallelgroup study. Clin Ther. 2006;1556-1568.

101. Hermansen K, Kipnes M, Luo E, Fanurik D, Khatami H, Stein P. Efficacy and safety of the dipeptidyl peptidase-4 inhibitor, sitagliptin, in patients with type 2 diabetes mellitus inadequately controlled on glimepiride alone or on glimepiride and metformin. Diabetes Obes Metab. 2007;9:733-745.

102. Nauck MA, Meininger G, Sheng D, Terranella L, Stein PP. Efficacy and safety of the dipeptidyl peptidase-4 inhibitor, sitagliptin, compared with the sulfonylurea, glipizide, in patients with type 2 diabetes inadequately controlled on metformin alone: a randomized double-blind, non-inferiority trial. Diabetes Obes Metab. 2007;9:194-205.

103. Migoya EM, Miller J, Larson P, et al. Sitagliptin, a selective DPP-4 inhibitor, and metformin have complementary effects to increase active GLP-1 concentrations. Diabetes. 2007;56:A74.

104. Bergman AJ, Cote J, Yi B, et al. Effect of renal insufficiency on the pharmacokinetics of sitagliptin, a dipeptidyl peptidase-4 inhibitor. Diabetes Care. 2007;30:1862-1864.

105. Galvus ${ }^{\circledR}$ Summary of Product Characteristics. Novartis Pte Ltd. http://emc.medicines.org.uk/. Accessed February 28, 2009.

106. Pi-Sunyer FX, Schweizer A, Mills D, Dejager S. Efficacy and tolerability of vildagliptin monotherapy in drug-naïve patients with type 2 diabetes. Diabetes Res Clin Pract. 2007;76:132-138.

107. Rosenstock J, Baron MA, Dejager S, Mills D, Schweizer. Comparison of vildagliptin and rosiglitazone monotherapy in patients with type 2 diabetes: a 24-week, double-blind, randomized trial. Diabetes Care. 2007;30:217-223.

108. Ahren B, Gomis R, Standl E, et al. twelve- and 52-week efficacy of the dipeptidyl peptidase IV inhibitor LAF237 in metformin-treated patients with type 2 diabetes. Diabetes Care. 2004;27:2874-2880.

109. Bosi E, Camisasca RP, Collober C, Rochotte E, Garber AJ. Effects of vildagliptin on glucose control over 24 weeks in patients with type 2 diabetes inadequately controlled with metformin. Diabetes Care. 2007;30:890-895.

110. Garber AJ, Schweizer A, Baron MA, Rochotte E, Dejager S. Vildagliptin in combination with pioglitazone improves glycemic control in patients with type 2 diabetes failing thiazolidinedione monotherapy: a randomized, placebo-controlled study. Diabetes Obes Metab. 2007;9:166-174.

111. Rosenstock J, Baron MA, Camisasca RP, et al. Efficacy and tolerability of initial combination therapy with vildagliptin and pioglitzone compared with component monotherapy in patients with type 2 diabetes. Diabetes Obes Metab. 2007;9:175-185.

112. D'Alessio DA, Denney AM, Hermiller LM. Treatment with the dipeptidyl peptidase-4 inhibitor vildagliptin improves fasting isletcell function in subjects with type 2 diabetes. $J$ Clin Endocrinol Metab. 2009;94:81-88.

113. Mari A, Scherbaum WA, Nilsson PM, et al. Characterization of the influence of vildagliptin on model-assessed -cell function in patients with type 2 diabetes and mild hyperglycemia. J Clin Endocrinol Metab. 2008;93:103-109. 
114. Vella A, Bock G, Giesler PD, et al. The effect of dipeptidyl peptidase-4 inhibition on gastric volume, satiation and enteroendocrine secretion in type 2 diabetes: a double-blind, placebo-controlled crossover study. Clin Endocrinol (Oxf). 2008;69:737-744.

115. Chan JC, Scott R, Arjona Ferreira JC. Safety and efficacy of sitagliptin in patients with type 2 diabetes and chronic renal insufficiency. Diabetes Obes Metab. 2008;10:545-555.

116. Covington P, Christopher R, Davenport M. Pharmacokinetic, pharmacodynamic, and tolerability profiles of the dipeptidyl peptidase-4 inhibitor alogliptin: a randomized, double-blind, placebocontrolled, multiple-dose study in adult patients with type 2 diabetes. Clin Ther. 2008;30:99-512.

117. DeFronzo RA, Fleck PR, Wilson CA, Mekki Q. Alogliptin Study 010 Group. Efficacy and safety of the dipeptidyl peptidase-4 inhibitor alogliptin in patients with type 2 diabetes and inadequate glycemic control: a randomized, double-blind, placebo-controlled study. Diabetes Care. 2008;31:2315-2317.

118. Nauck MA, Ellis GC, Fleck PR, Wilson CA, Mekki Q. Alogliptin Study 008 Group. Efficacy and safety of adding the dipeptidyl peptidase-4 inhibitor alogliptin to metformin therapy in patients with type 2 diabetes inadequately controlled with metformin monotherapy: a multicentre, randomised, double-blind, placebo-controlled study. Int J Clin Pract. 2009;63:46-55.

119. Pratley RE, Kipnes MS, Fleck PR, Wilson C, Mekki Q. Alogliptin Study 007 Group. Diabetes Obes Metab. 2009;11:167-176.

120. Moritoh Y, Takeuchi K, Asakawa T, Kataoka O, Odaka H. Combining a dipeptidyl peptidase- 4 inhibitor, alogliptin, with pioglitazone improves glycaemic control, lipid profiles and beta-cell function in db/db mice. Br J Pharmacol. 2009;157:415-426.

121. Pratley JE. Alogliptin: a new, highly selective dipeptidyl peptidase-4 inhibitor for the treatment of type 2 diabetes. Expert Opin Pharmacother. 2009;10:503-512.

122. Rosenstock J, Sankoh S, List JF. Glucose-lowering activity of the dipeptidyl peptidase-4 inhibitor saxagliptin in drug-naïve patients with type 2 diabetes. Diabetes Obes Metab. 2008;10:376-388.

123. DeFronzo RA, Hissa M, Blauwet MB, Chen RS. Saxagliptin added to metformin improves glycemic control in patients with type 2 diabetes [abstract]. Diabetes. 2007;56(Suppl 1):A74.

124. Ravichandran S, Chacra AR, Tan GH, Apanovitch AM, Chen R. Saxagliptin added to a sub-maximal dose sulfonylurea is safe and more efficacious than up-titrating a sulfonylurea in patients with type 2diabetes [abstract]. Diabetologia. 2008;51(Suppl 1):S342.

125. Hollander P, Allen E, Li J, Chen R. Saxagliptin added to a thiazolidinedione improves glycemic control in patients with inadequately controlled type 2 diabetes [abstract]. Diabetologia. 2008; 51(Suppl 1):S342.

126. Deacon CF, Holst JJ. Saxagliptin: a new dipeptidyl peptidase-4 inhibitor for the treatment of type 2 diabetes. Adv Ther. 2009;26:488-499.

127. Viswanathan $P$, Chaudhuri A, Bhatia R, et al. Exenatide therapy in obese patients with type 2 diabetes mellitus treated with insulin. Endocr Pract. 2007;13:444-450.

128. Ratner RE, Maggs D, Nielsen LL, et al. Long-term effects of exenatide therapy over 82 weeks on glycaemic control and weight in overweight metformin-treated patients with type 2 diabetes mellitus. Diabetes Obes Metab. 2006;8:419-428.

129. Klonoff DC, Buse JB, Nielsen LL, et al. Exenatide effects on diabetes, obesity, cardiovascular risk factors and hepatic biomarkers in patients with type 2 diabetes treated for at least 3 years. Curr Med Res Opin. 2008;24:275-286.

130. Sonne DP, Engstrom T, Treiman M. Protective effects of GLP-1 analogues exendin-4 and GLP-1 (9-36) amide against ischemiareperfusion injury in rat heart. Regul Pept. 2008;146:243-249.

131. Noyan-Ashraf MH, Ban K, Sadi A, et al. The GLP-1R agonist liraglutide protects cardeomyocytes and improved survival and cardiac function after experimental murine infarction [abstract 190-OR]. Presented at the 68th Scientific Sessions of the American Diabetes Association. San Francisco, CA; June 6-10, 2008.
132. Courreges JP, Vilsboll T, Zdravkovic M, et al. Beneficial effects of once-daily liraglutide, a human glucagon-like peptide-1 analogue, on cardiovascular risk biomarkers in patients with Type 2 diabetes. Diabet Med. 2008;25:1129-1131.

133. Mistry GC, Maes AL, Lasseter KC, et al. Effect of sitagliptin, a dipeptidyl peptidase-4 inhibitor, on blood pressure in nondiabetic patients with mild to moderate hypertension. J Clin Pharmacol. 2008; 48:592-598.

134. Scott R, Wu M, Sanchez M, et al. Efficacy and tolerability of the dipeptidyl peptidase-4 inhibitor sitagliptin as monotherapy over 12 weeks in patients with type 2 diabetes. Int J Clin Pract. 2007;61:171-180.

135. Bolli G, Dotta F, Rochotte E, et al. Efficacy and tolerability of vildagliptin vs. pioglitazone when added to metformin: a 24-week, randomized, double-blind study. Diabetes Obes Metab. 2008;10:82-90.

136. Matikainen N, Mänttäri S, Schweizer A, et al. Vildagliptin therapy reduces postprandial intestinal triglyceride-rich lipoprotein particles in patients with type 2 diabetes. Diabetologia. 2006;49:2049-2057.

137. Boschmann M, Engeli S, Dobberstein K, et al. Dipeptidylpeptidase-IV inhibition augments postprandial lipid mobilization and oxidation in type 2 diabetic patients. J Clin Endocrinol Metab. 2009;94:846-852.

138. Jones KL, Russo A, Berry MK, et al. A longitudinal study of gastric emptying and upper gastrointestinal symptoms in patients with diabetes mellitus. Am J Med. 2002;113:449-455.

139. Delgado-Aros S, Vella A, Camilleri M, et al. Effects of glucagon-like peptide 1 and feeding on gastric volumes in diabetes mellitus with cardio-vagal dysfunction. Neurogastroenterol Motil. 2007;15:435-443.

140. Food and Drug Administration Information for Healthcare Professionals Exenatide (marketed as Byetta). www.fda.gov/cder/drug/ InfoSheets/HCP/exenatideHCP.htm. Accessed August 3, 2009.

141. Noel RA, Braun DK, Patterson RE, Bloomgren G. Increased risk of acute pancreatitis and biliary disease observed in patients with type 2 diabetes: a retrospective cohort study, Diabetes Care. 2009; 32:834-838.

142. http://www.fda.gov/ohrms/dockets/ac/09/briefing/2009-4422b2-02NovoNordisk.pdf p 89-95. Accessed May 8, 2009.

143. Koehler JA, Baggio LL, Lamont BJ, Ali S, Drucker DJ. GLP-1 receptor activation modulates pancreatitis-associated gene expression but does not modify the susceptibility to experimental pancreatitis in mice. Diabetes. 2009 Jun 9. [Epub ahead of print].

144. Matveyenko AV, Dry S, Cox HI, et al. Beneficial endocrine but adverse exocrine effects of sitagliptin in the human islet amyloid polypeptide transgenic rat model of type 2 diabetes: interactions with metformin. Diabetes. 2009;58:1604-1615.

145. Kieffer TJ, McIntosh CH, Pederson RA. Degradation of glucosedependent insulinotropic polypeptide and truncated glucagonlike peptide 1 in vitro and in vivo by dipeptidyl peptidase IV. Endocrinology. 1995;136:3585-3596.

146. De Meester I, Lambeir AM, Proost P, et al. Dipeptidyl peptidase IV substrates: an update on in vitro peptide hydrolysis by human DPPIV. Adv Exp Med Biol. 2003;524:3-17.

147. Busso N, Wagtmann N, Herling C, et al. Circulating CD26 is negatively associated with inflammation in human and experimental arthritis. Am J Pathol. 2005;166:433-442.

148. Minshall ME, Oglesby AK, Wintle ME. Estimating the long-term cost-effectiveness of exenatide in the United States: an adjunctive treatment for type 2 diabetes. Value Health. 2008;11:22-33.

149. Ray JA, Boye KS, Yurgin N, et al. Exenatide versus insulin glargine in patients with type 2 diabetes in the UK: a model of long-term clinical and cost outcomes. Curr Med Res Opin. 2007;23:609-622.

150. Woehl A, Evans M, Tetlow AP, McEwan P. Evaluation of the cost effectiveness of exenatide versus insulin glargine in patients with sub-optimally controlled type 2 diabetes in the United Kingdom. Cardiovasc Diabetol. 2008;7:24.

151. Boye KS, Matza LS, Oglesby A, et al. Patient-reported outcomes in a trial of exenatide and insulin glargine for the treatment of type 2 diabetes. Health Qual Life Outcomes. 2006;4:80. 
152. Schwarz B, Gouveia M, Chen J, et al. Cost-effectiveness of sitagliptin-based treatment regimens in European patients with type 2 diabetes and haemoglobin $\mathrm{A}_{1 \mathrm{c}}$ above target on metformin monotherapy. Diab Obes Metab. 2008;10:43-55.

153. Scott R, Loeys T, Davies MJ, Engel SS. Efficacy and safety of sitagliptin when added to ongoing metformin therapy in patients with type 2 diabetes. Diabetes Obes Metab. 2008;10:959-969.

154. Lage MJ, Fabunmi R, Boye KS, Misurski DA. Comparison of costs among patients with type 2 diabetes treated with exenatide or sitagliptin therapy. Adv Ther. 2009;26:217-229.

155. Jellinger PS, Davidson JA, Blonde L, et al. Road maps to achieve glycemic control n type 2 diabetes mellitus. Endocr Pract. 2007; 13:261-268.

156. Nathan DM, Buse JB, Davidson MB, et al. Medical management of hyperglycemia in type 2 diabetes: a consensus algorithm for the initiation and adjustment of therapy. Diabetes Care. 2008; 31:1-11.

157. Nauck MA, Walberg J, Vethacke A, et al. Blood glucose control in healthy subject and patients receiving intravenous glucose infusion or total parenteral nutrition using glucagon-like peptide 1. Regul Pept. 2004;118:89-97.

158. Meier JJ, Weyhe D, Michaely M, et al. Intravenous glucagon-like peptide 1 normalizes blood glucose after major surgery in patients with type 2 diabetes. Crit Care Med. 2004;32:848-851.
159. Deane AM, Chapman MJ, Fraser RJ, Burgstad C, Besanko LK, Horowitz M. The effect of exogenous glucagon-like peptide-1 on the glycaemic response to small intestinal nutrient in the critically ill: a randomised double-blind placebo controlled cross over study. Crit Care. 2009;13:R67. (Epub May 14).

160. NICE-SUGAR Study Investigators, Finfer S, Chittock DR, Su SY, et al. Intensive versus conventional glucose control in critically ill patients. N Engl J Med. 2009;360:1283-1297.

161. Asche CV, McAdam-Marx C, Shane-McWhorter L, et al. Evaluation of adverse events of oral antihyperglycemic monotherapy experienced by a geriatric population in a real-world setting: a retrospective cohort analysis. Drugs Aging. 2008;25:611-622.

162. Hanefeld M, Herman GA, Wu M, et al. Once-daily sitagliptin, a dipeptidyl peptidase-4 inhibitor, for the treatment of patients with type 2 diabetes. Curr Med Res Opin. 2007;23:1329-1339.

163. Pratley RE, Rosenstock J, Pi-Sunyer FX, et al. Management of type 2 diabetes in treatment-naive elderly patients: benefits and risks of vildagliptin monotherapy. Diabetes Care. 2007;30:3017-3022.

164. Migoya EM, Stevens CH, Bergman AJ, et al. Effect of moderate hepatic insufficiency on the pharmacokinetics of sitagliptin. Can J Clin Pharmacol. 2009;16:e165-e170.

165. Chan JC, Scott R, Arjona Ferreira JC, et al. Safety and efficacy of sitagliptin in patients with type 2 diabetes and chronic renal insufficiency. Diabetes Obes Metab. 2008;10:545-555.
Therapeutics and Clinical Risk Management

\section{Publish your work in this journal}

Therapeutics and Clinical Risk Management is an international, peerreviewed journal of clinical therapeutics and risk management, focusing on concise rapid reporting of clinical studies in all therapeutic areas, outcomes, safety, and programs for the effective, safe, and sustained use of medicines. This journal is indexed on PubMed Central, CAS,

\section{Dovepress}

EMBase, Scopus and the Elsevier Bibliographic databases. The manuscript management system is completely online and includes a very quick and fair peer-review system, which is all easy to use. Visit $\mathrm{http}: / / \mathrm{www}$.dovepress.com/testimonials.php to read real quotes from published authors. 